\title{
COLD STRATIFICATION BREAKS THALICTRUM UCHIYAMAE NAKAI SEED DORMANCY VIA PROTEOMIC CHANGES
}

\author{
LEE, H. $.^{*}-$ KIM, J. ${ }^{1}-$ GHIMIRE, B. ${ }^{2}-$ JUNG, M. J. $^{3}-$ SUH, G. U. ${ }^{4}$ \\ ${ }^{1}$ Seed Vault Center, Baekdudaegan National Arboretum, Bonghwa 36209, Republic of Korea \\ (phone: +82-54-679-2770; fax: +82-54-679-0960) \\ ${ }^{2}$ Forest Biodiversity Research Division, Korea National Arboretum, Pocheon 11186, Republic \\ of Korea \\ (phone: +82-31-054-8814; fax: +82-31-054-8800) \\ ${ }^{3}$ Plant Resource Research division, Korea National Arboretum, Pocheon 11186, Republic of \\ Korea \\ (phone: +82-31-540-2349; fax: +82-31-771-2739)
}

${ }^{4}$ Arboretum Division, Korea National Arboretum, Pocheon 11186, Republic of Korea

(phone: +82-31-540-1041; fax: +82-31-540-2049)

${ }^{*}$ Corresponding author

e-mail: hayanlee12@gmail.com; phone: +82-54-679-2770; fax: +82-679-0960

(Received 22 $2^{\text {nd }}$ Mar 2021; accepted $19^{\text {th }}$ Jul 2021)

\begin{abstract}
This study was conducted to obtain basic data related to the seeds, germination conditions, and physiological changes in the seeds of Thalictrum uchiyamae Nakai (Seoul Meadow Rue). The seed was elongated and tapering at both ends, and its length and width were $1.810-2.744$ and $0.576-0.989 \mathrm{~mm}$, respectively. When the seeded seeds were planted immediately, the germination rate was less than $5 \%$ at $15 / 6^{\circ} \mathrm{C}$ or $20 / 10^{\circ} \mathrm{C}$, but after cold stratification for 8 weeks at $5^{\circ} \mathrm{C}$, the germination rate exceeded $80 \%$ at $30 / 20^{\circ} \mathrm{C}, 20 / 10^{\circ} \mathrm{C}$, and $15 / 6^{\circ} \mathrm{C}$. Thus, it was confirmed that $T$. uchiyamae seeds are morphophysiologically dormant. The physiological changes in the seeds during cold stratification were investigated in terms of proteomics; the number of activated proteins increased from 330 to 353 after cold stratification. We confirmed that the disappearance of or decrease in tunicamycin and phytochrome is associated with the breaking of dormancy in T. uchiyamae seeds.
\end{abstract}

Keywords: morphophysiological dormancy, phytochrome, proteomics, Ranunculaceae, tunucamycycin

\section{Introduction}

Dormancy is a peculiar characteristic of seeds; it prevents germination and the subsequent growth of seedlings under unsuitable ecological and environmental conditions (Bewley et al., 2006). Seed dormancy can be divided according to the region and mode of dormancy (Fenner et al., 2005). Baskin and Baskin (2004) classified dormancy types into physiological, morphological, morphophysiological, physical, and combined dormancy.

Seed germination is mainly determined by the plant hormones abscisic acid (ABA) and gibberellin (Razem et al., 2006; Weiss and Ori, 2007). It is not limited thereto, and the presence/absence or activity of various proteins is widely influenced by physiological changes within the seed during germination (Satoh and Esashi, 1979). Proteomics is the large-scale study of proteins, which are an important component of living organisms owing to their various functions (Blackstock and Weir, 1999). It involves the analysis of proteins that are produced, lost, or modified by various systems of an organism. Thus, proteomics supports functional genomics, which analyzes use of genetic information by functional 
distinction, according to the situation (Anderson et al., 2016). Nevertheless, plant proteomics is still in an early stage and is focused on intracellular proteomes and protein complexes, for example, proteins in the plasma membrane and chloroplast (Rouquie et al., 1997; Bae et al., 2003; Park, 2004). Seed proteomics focuses on seed development, drying tolerance, germination, qualitative and quantitative changes in the proteome during dormancy, changes in vitality, and responses to environmental factors. It has been mainly applied to study model species such as Arabidopsis and important economic crops such as corn and rice (Weiss and Ori, 2007; Kim et al., 2008; He and Yang, 2013; Wang et al., 2015). Through protein profiling, mechanisms of physiological changes in seeds such as metabolism, cell cycle, signaling, and protein-related pathways can be elucidated (Wang et al., 2012).

Ranunculaceae members are distributed worldwide, with 43 genera and 2346 species accounting for approximately $0.8 \%$ of all flowering plants (Christenhusz and Byng, 2016). The seeds of most Ranunculaceae members are desorbed from the parent plant along with the immature embryo. Accordingly, dormancy in most Ranunculaceae members has been reported to be morphophysiological, which requires additional physiological treatments, such as gibberellin treatment and cold stratification, to break dormancy and allow immature embryo development and germination (Hepher and Roberts, 1985; Walck et al., 2000).

Thalictrum L. is one of the largest taxa of the family Ranunculus, and 120-200 species are distributed in most temperate regions (Pajeva et al., 2004). There are several studies on the pharmacological effects of Thalictrum species, because they possess several compounds, such as alkaloids, that exhibit anticancer and antibacterial activities (Chen et al., 1993; Pajeva et al., 2004). Thalictrum uchiyamae Nakai. (Seoul meadow rue) is a perennial herb that grows in various parts of Korea; they mostly grow among wet rocks and in semi-shaded organic soil. The plant grows to a height of approximately $50 \mathrm{~cm}$, blooms with white-purple flowers in June and July, and bears semi-elliptical fruit in August and September (Park and Park, 2008). Young shoots are edible and are mainly used for gardening and ornamental purposes. Thalictrum uchiyamae is considered a useful medicinal plant in the Orient, because its rhizomes and roots contain high amounts of alkaloids such as thalicarpine, which reduce inflammation and act as diuretic and antibacterial agents (Bang, 1982; Lee, 1984; Kim, 1993).

Thalictrum uchiyamae was known to be endemic to the Korean Peninsula, but it was excluded from the revised endemic plant list in 2017, following the confirmation of its distribution in Japan (Iwatsuki et al., 2006; Chung et al., 2017). Nevertheless, countries are strengthening their bio-sovereignty with the international implementation of the Convention on Biological Diversity and the Nagoya Protocol. It is apparent that T. uchiyamae, which has a high value as a horticultural and medicinal resource, is still a priority consideration for Korea's bio-sovereignty (Paik, 1999; Oh et al., 2005). The pharmaceutical effects of T. uchiyamae, such as its antibacterial activity, have been well studies (Lee and Lee, 1982; Lee, 1984); furthermore, T. uchiyamae seed germination has been studied in external soil (Lee et al., 2018). Uniform propagation of T. uchiyamae in the laboratory is required for mass proliferation, continued use, and utilization of its pharmacological effects.

In physiological studies of seeds, storage proteins, stress responses, and proteomic changes due to germination have been extensively studied in crops such as beans and rice (Yang et al., 2007; De La Fuente et al., 2011; Badowiec and Weidner, 2014). However, physiological studies of seeds of wild plant have been limited to Aconitum or Podophyllum (Dogra et al., 2013; Rana and Sreenivasulu, 2013). 
The main purposes of this study were to analyze the dormancy type of $T$. uchiyamae seeds and to establish uniform germination conditions for T. uchiyamae seeds in the laboratory. Additionally, we performed proteomic analysis to elucidate the physiological changes, mainly proteomic changes, in seeds during dormancy breaking and to identify the associated proteins.

\section{Materials and methods}

\section{Seed collection and characterization (plant material)}

Fruits of T. uchiyamae were collected in Mt. Gaji, Cheongdo-gun, Gyungsangbuk-do, South Korea, in September 2013. Mature seeds were dried at room temperature for 1 month and stored at $4^{\circ} \mathrm{C}$ until use. The 1000 -seed weight was measured using an electronic scale. The seed shape, size, and color and embryo length were measured using a Leica MZ16FA stereomicroscopic zoom microscope (Leica, Germany). Furthermore, the embryo:seed ratio (E:S ratio) at each germination stage were calculated (Vandelook et al., 2007).

\section{Germination of seeds}

For cold stratification, the seeds were treated at $5^{\circ} \mathrm{C}$ for $2,4,8$, and 12 weeks, and then incubated at three temperature conditions: $15 / 6^{\circ} \mathrm{C}, 20 / 10^{\circ} \mathrm{C}$, and $30 / 20^{\circ} \mathrm{C}$ with a $14-\mathrm{h}$ photoperiod in a Bio Multi Incubator (LH-30-8CT, NK System Co., Japan). As controls, untreated seeds were also simultaneously placed in the incubator. In all experiments, the seeds were placed on $8 \%(\mathrm{w} / \mathrm{v})$ agar medium in a Petri dish $(90 \mathrm{~mm}$ in diameter) with three replicates of 30 seeds. Germination was recorded daily for up to 30 days, and the seeds were considered germinated when the radicle was $1 \mathrm{~mm}$ long. Final germination percentage (FGP) was compared to the mean germination time (MGT), germination index (GI), and final germination date (FGD) (Scott et al., 1984).

$$
\begin{aligned}
\mathrm{MGT} & =\Sigma(\mathrm{TiNi}) / \mathrm{N} \\
\mathrm{GI} & =\Sigma \mathrm{TiNi} / \mathrm{S}
\end{aligned}
$$

where, Ti: number of days after sowing, Ni: number of seeds germinated on day i, N: total number of germinated seeds, S: number of seeds sown.

\section{Protein extraction and electrophoresis}

Untreated and chilling-treated seeds were used for protein extraction. Total soluble proteins were extracted from 50 seeds under each condition using the P-PER ${ }^{\circledR}$ Plant Protein Extraction Kit (Thermo Scientific, USA). Elution buffer was replaced with cell lysis solution, containing $7 \mathrm{M}$ urea, $2 \mathrm{M}$ thiourea, 4\% (w/v) CHAPS, 2.5\% (w/v) DTT, and protease inhibitor (Roche, USA), for electrophoresis. Protein concentrations were determined using the Bradford method and rechecked by 1-D electrophoresis on 12\% 1D sodium dodecyl sulfate-polyacrylamide gel. For 2D-analysis, $700 \mu \mathrm{g}$ of each protein was loaded onto a 3-10 pH IPG strip (Amersham, USA), and 2D-separations were performed on 12\% SDS-PAGE gel. The gels were fixed and stained with Coomassie brilliant blue G-250 solution and de-stained with acetic acid (ProteomeTech Inc., South Korea). 


\section{Protein analysis}

2D pattern matching with protein spots was performed using 2D Platinum software version 5.0 (GE Healthcare, USA). Proteins with more than two-fold changes between the control and treatments were compared. Gel digestion of protein spots was performed, and then LC-MS/MS analysis was conducted at ProteomeTech (Seoul, South Korea) to identify proteins. Peptide spectra of LC-MS/MS were identified against NCBI using MASCOT software (Matrix Science, London, UK).

\section{Data analysis}

A completely randomized design with three replications was used. Data were analyzed using the two-way ANOVA with the SPSS statistical package, version 17.0. Treatment means were compared using Tukey's HSD mean separation at the $1 \%$ probability level.

\section{Results}

\section{Seed morphology}

The seeds were 1.810-2.744 $\mathrm{mm}$ in length, $0.576-0.989 \mathrm{~mm}$ in width, and the weight of thousand seeds was $0.601-0.811 \mathrm{~g}$ (Table 1). The seeds were elongated and tapering at both ends, and they were dark brown to black (Fig. 1A, Table 1).

Table 1. Characteristics of the fruit and seed of T. uchiyamae used in this study

\begin{tabular}{c|c|c|c|c|c|c}
\hline Fruit type & Seed shape & $\begin{array}{c}\text { Seed length } \\
\mathbf{( m m )}\end{array}$ & $\begin{array}{c}\text { Seed width } \\
\mathbf{( m m )}\end{array}$ & $\begin{array}{c}\text { 1,000-seed } \\
\text { weight } \\
\mathbf{( g )}\end{array}$ & Embryo type & E:S ratio* \\
\hline Achene & $\begin{array}{c}\text { Elongated and } \\
\text { tapering at } \\
\text { both ends }\end{array}$ & $1.810-2.744$ & $0.576-0.989$ & $0.601-0.811$ & $\begin{array}{c}\text { Rudimentary } \\
\text { linear }\end{array}$ & 0.15 \\
\hline
\end{tabular}

A rudimentary linear embryo was observed in T. uchiyamae seeds (Fig. 1A). The E:S ratio revealed that the undeveloped embryo occupied less than $15 \%$ of the seed (Fig. IB).

\section{Germination after cold stratification}

Matured seeds of T. uchiyamae did not germinate at $30^{\circ} \mathrm{C} / 20^{\circ} \mathrm{C}$; only $3.3 \%$ of the seeds germinated at $20^{\circ} \mathrm{C} / 10^{\circ} \mathrm{C}$ and $15^{\circ} \mathrm{C} / 6^{\circ} \mathrm{C}$ during 4 weeks (Fig. 1C). Unlike the untreated seeds, the seeds treated at low temperatures germinated (Table 2). When the period of cold stratification was shorter than 2 weeks, the germination rate at $15^{\circ} \mathrm{C} / 6^{\circ} \mathrm{C}$ was higher than that at other germination temperatures. At a cold stratification period of more than 4 weeks, seeds at warm temperatures, such as $20^{\circ} \mathrm{C} / 10^{\circ} \mathrm{C}$ and $30^{\circ} \mathrm{C} / 20^{\circ} \mathrm{C}$, presented a higher germination rate than those at $15^{\circ} \mathrm{C} / 6^{\circ} \mathrm{C}$. Particularly, final germination was more than $80 \%$ at warm germination temperatures after cold stratification for 8 weeks.

The embryo of $T$. uchiyamae seeds did not develop with cold or warm stratification (Fig. 2); however, a rapid development of embryos was observed at a warm germination temperature after cold stratification (Fig. 3). The results showed that the germination temperature and cold stratification period play a major role in the germination of T. uchiyamae seeds. 


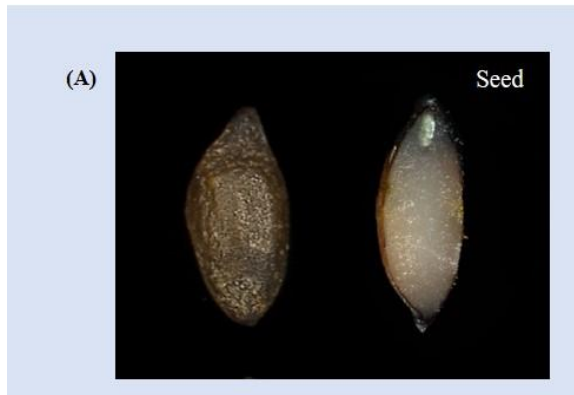

(B)

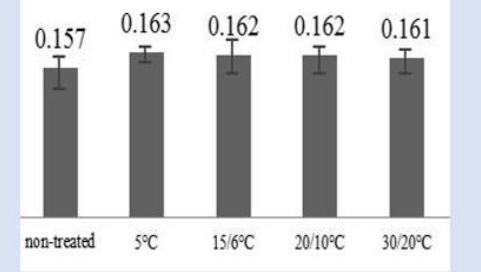

(C)

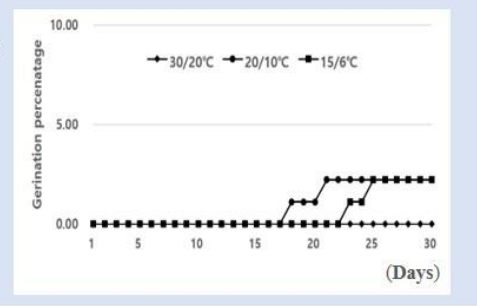

Figure 1. Basic characteristics of $T$. uchiyamae seeds. (A) Seed and cross section containing rudimentary embryo.

(B) Embryo/seed ratio when incubated for 1 month at each temperature $(C)$

Germination rate graph at each temperature for the untreated

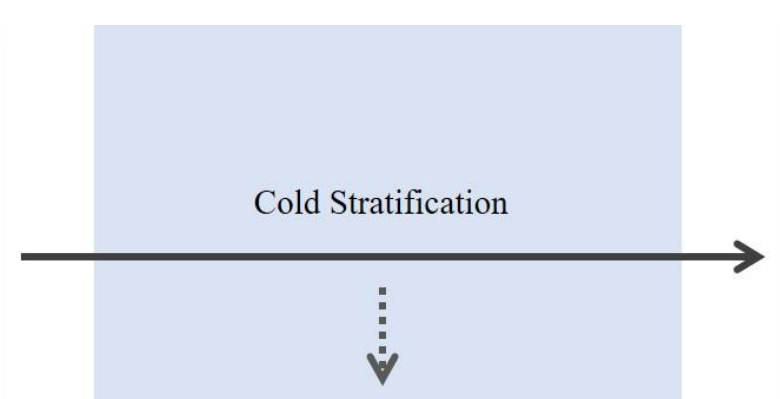

(A) 0.354
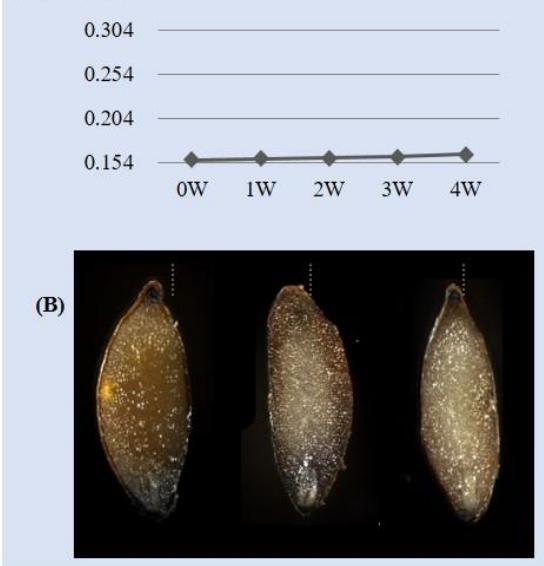

Figure 2. Embryo was not grown during Figure 3. Embryo development after cold cold stratification. (A) E:S ratio depends on cold stratification period. (B) Pictures of the embryo at week 0, 2, 4 after cold stratification

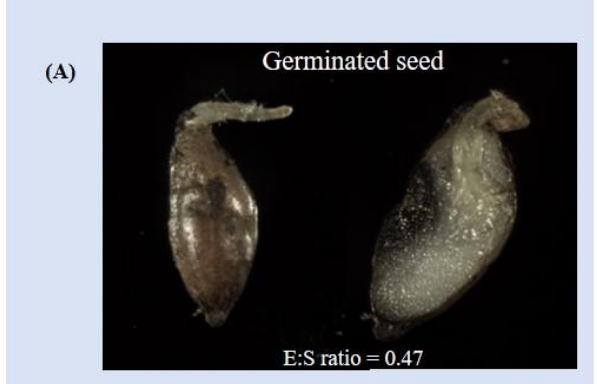

(B) 0.354

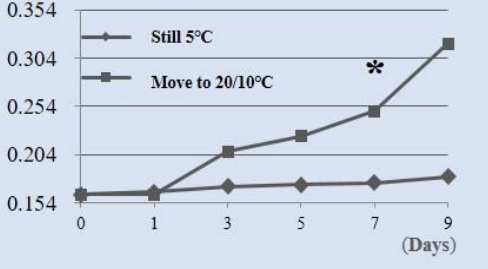

(C)

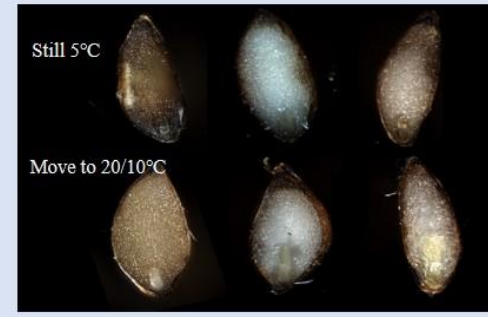
stratification. (A) The radicle appeared after cold stratification. (B) E:S ratio at different temperatures after 4 weeks of cold stratification. (C) Pictures of the embryo on day 1, 5, 9 at 5 or $20 / 10^{\circ} \mathrm{C}$ after 4 weeks of cold stratification. * Start day of germination 
Table 2. Seed germination depends on the cold stratification period and germination temperature. The letters beside numeric values indicate significant differences by Tukey' HSD test. CS period, cold stratification period; GT, germination temperature; FGP, final germination percentage; MGT, mean of germination time; FGD, final germination date

\begin{tabular}{c|c|c|c|c}
\hline $\begin{array}{c}\text { CS period } \\
\text { (weeks) }\end{array}$ & $\begin{array}{c}\text { GT } \\
\left({ }^{\circ} \mathrm{C}\right)\end{array}$ & $\begin{array}{c}\text { FGP } \\
(\%, \pm \text { SD) }\end{array}$ & $\begin{array}{c}\text { MGT } \\
(\text { days, } \pm \text { SD })\end{array}$ & $\begin{array}{c}\text { FGD } \\
(\mathbf{d a y})\end{array}$ \\
\hline \multirow{2}{*}{0} & $30 / 20$ & 0.00 & - & - \\
& $20 / 10$ & $3.33 \pm 0 \mathrm{a}$ & $23.00 \pm 6.24 \mathrm{ab}$ & 30 \\
& $15 / 6$ & $3.33 \pm 0 \mathrm{a}$ & $26.00 \pm 3.61 \mathrm{a}$ & 30 \\
\hline \multirow{2}{*}{2} & $30 / 20$ & $57.30 \pm 1.2 \mathrm{~b}$ & $11.18 \pm 0.98 \mathrm{e}$ & 17 \\
& $20 / 10$ & $78.70 \pm 1.2 \mathrm{cde}$ & $13.73 \pm 0.31 \mathrm{cde}$ & 27 \\
& $15 / 6$ & $74.70 \pm 4.0 \mathrm{bcd}$ & $22.67 \pm 1.41 \mathrm{ab}$ & 30 \\
\hline \multirow{3}{*}{8} & $30 / 20$ & $94.70 \pm 0.6 \mathrm{e}$ & $13.65 \pm 1.65 \mathrm{cde}$ & 28 \\
& $20 / 10$ & $90.70 \pm 1.2 \mathrm{de}$ & $11.20 \pm 0.48 \mathrm{de}$ & 21 \\
& $15 / 6$ & $64.00 \pm 1.7 \mathrm{bc}$ & $19.38 \pm 1.45 \mathrm{abc}$ & 27 \\
\hline \multirow{3}{*}{12} & $30 / 20$ & $85.30 \pm 2.3 \mathrm{de}$ & $10.29 \pm 0.77 \mathrm{de}$ & 23 \\
& $20 / 10$ & $90.70 \pm 0.6 \mathrm{de}$ & $9.46 \pm 1.08 \mathrm{e}$ & 18 \\
& $15 / 6$ & $84.00 \pm 1.7 \mathrm{de}$ & $17.86 \pm 0.46 \mathrm{cde}$ & 24 \\
\hline & $30 / 20$ & $89.30 \pm 1.2 \mathrm{de}$ & $6.78 \pm 1.02 \mathrm{e}$ & 17 \\
\hline
\end{tabular}

FGP and MGT data are presented as mean and standard deviation (SD)

\section{Proteomic changes in the germination stage}

To examine the physiological changes in the seeds induced by cold treatment, the changes in seed proteins were compared through 2D electrophoresis. In total, 330 proteins were detected in the untreated seeds and 353 proteins in the cold-stratified seeds; all proteins were found to be expressed between $\mathrm{pH} 4$ and 8; their molecular weights ranged between 15 and $60 \mathrm{kD}$.

A total of 47 altered proteins were found based on the differences (two-fold or higher) in the protein expression pattern between the untreated and cold-stratified seeds. The expression of 7 proteins increased and that of 27 proteins decreased; 4 proteins appeared and 9 proteins disappeared (Fig. 4). Among the proteins with differences, we identified 16 proteins with the greatest changes, namely, 2 increased, 7 decreased, 4 appeared, and 3 disappeared proteins (Supplementary Table 1). Specifically, we confirmed the disappearance of tunicamycin (Spot 1) and reduction in phytochrome (Spot 31) (Fig. 5).
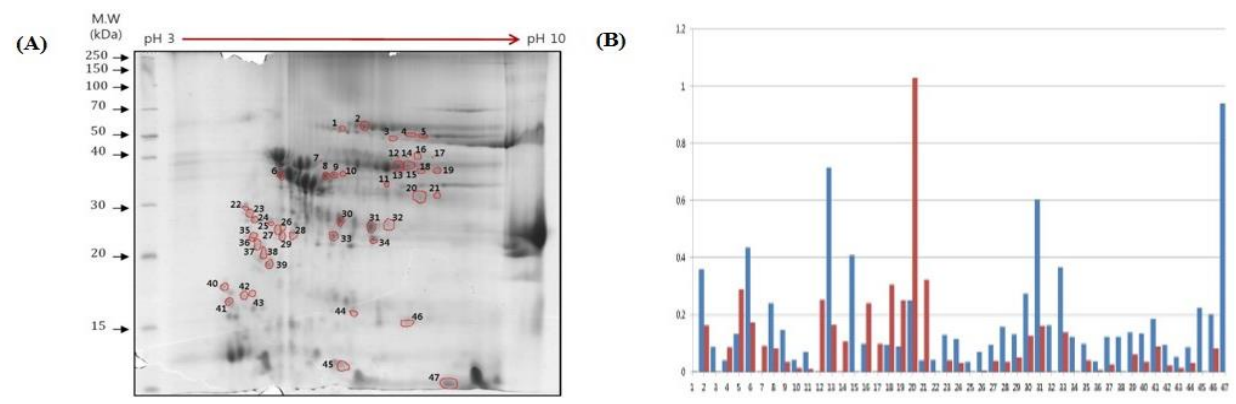

Figure 4. Proteins whose expression altered after cold stratification. (A) Fotrty-seven proteins whose expression was altered at pH 6-8 were identified (molecular weight 40-70 kD) using 2D SDS-PAGE. (B) Quantitative comparison of proteins whose expression had altered before and after cold stratification 
(A)
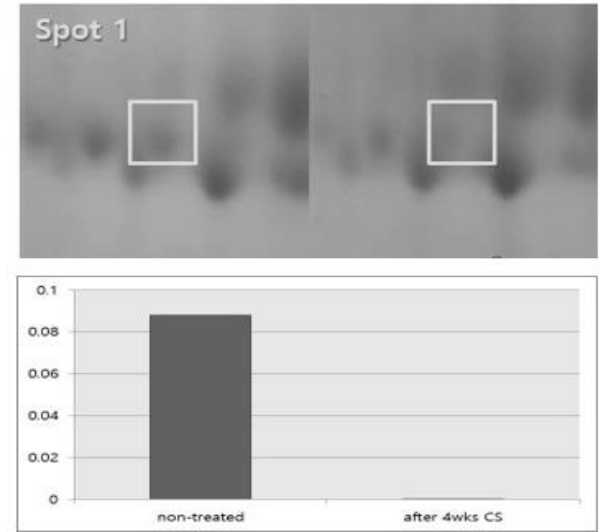

(B)

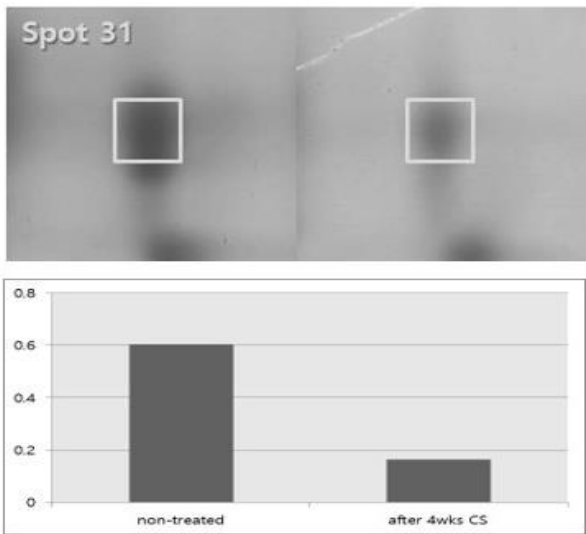

Figure 5. Changes in spots 1 and 31 after cold stratification. (A) Spot 1 disappeared after cold stratification, $(B)$ The intensity of Spot 31 rapidly decreased during cold stratification

\section{Discussion}

Narrow, elliptic, or fusiform, dark brown to black seeds of $T$. uchiyamae are known to belong to the section physocarpum (Ghimire et al., 2016). Martin's seed internal classification is based on the fact that some Ranunculaceae seeds contain an undeveloped linear embryo surrounded by the endosperm (Martin, 1946). It is known that immature seeds (without a fully developed embryo) of Ranunculaceae members shed from the mother plants, and some species, especially those that shed their seeds in the spring or/and summer, are known to have morphologically undeveloped embryos (Earle, 1938; Tamura and Mizumoto, 1972; Engell, 1995).

Dormancy of seeds with undeveloped embryos is classified as follows: 1) morphological dormancy (MD), when the embryos do not grow to a certain size; 2) physiological dormancy (PD) caused by the physiological inhibition of the embryo; and 3) morphophysiological dormancy (MPD), coexistence of morphological and physiological dormancy (Nikolaeva, 1969). Seeds with MD generally germinate at the germination temperature under wet conditions at 4 weeks. PD of seeds is broken by resolving the physiological inhibition mechanism with cold or warming treatment. Accordingly, MPD is broken when the treatments of both MD and PD are applied; thereafter, the embryos grow and the seeds germinate (Baskin and Baskin, 2004).

Embryo development at all germination temperatures was not achieved at 30 days (data not shown); therefore, the dormancy type of T. uchiyamae seeds is MPD, which has to be broken for the transition of physiological mechanisms and embryo growth.

MPD is classified into a simple or complex type based on the temperature of embryo growth. In addition, classification types based on physiological dormancy depth; nondeep, intermediate, and deep exist (Baskin and Baskin, 1998). Here, the embryos did not grow during cold stratification, but the physiological inhibition mechanism was broken, and complete development of the embryo was achieved after the seeds were moved to a warm temperature. According to these results, the dormancy type of T. uchiyamae is nondeep, simple MPD. The seeds of Thalictrum mirabile are also known to have non-deep, simple MPD (Wang et al., 2012), thus supporting our result.

The seeds of plants that sprout in the spring, such as Aruncus dioicus and Primula sieboldii, are commonly dormant in winter, and cold stratification is the usual treatment to break their dormancy (Salisbury and Ross, 1985; Hong et al., 2006; Song et al., 2015). 
It is thought that continuous chilling and wet conditions affect germination (Bewley and Black, 1994). Other studies have reported that the optimum germination temperatures in many spring- or summer-germinating species are high $\left(20^{\circ} \mathrm{C}-30^{\circ} \mathrm{C}\right)$ after chilling (Baskin and Baskin, 1987; Matsuo and Kubota, 1988). Thus, this result shows that 1) more than 4 weeks of cold stratification is needed to break dormancy and 2) warm temperatures are necessary for seeds of T. uchiyamae to germinate.

Tunicamycin (Spot 1) induces protein accumulation and endoplasmic reticulum stress, and is known as a major protein involved in apoptosis (Reis et al., 2011; Barba-Espín et al., 2014). Here, it disappeared after cold stratification (Fig. 5A). In contrast to the decay and apoptosis observed in many untreated seeds, the disappearance of tunicamycin induces a reduction in contamination due to the risk of cell death. As a result, seeds under low-temperature conditions can maintain a germination-ready state.

Phytochrome (Spot 31) is known to be involved in the activity of genes required for germination stimulation by breaking seed dormancy (Shin et al., 2016). In the present study, its expression decreased during cold stratification in the dark (Fig. 5B). This suggests that there would be a delay in seed germination at cold temperatures until optimal warm germination conditions are reached.

\section{Conclusion}

The seeds of T. uchiyamae have an immature embryo during desorption, and the dormancy of seeds can be effectively broken through cold stratification under dark conditions. Our findings showed that $T$. uchiyamae seeds have morphophysiological dormancy, which can be broken at a low temperature; embryo development can occur at appropriate warm temperature for germination. During pre-treatment (low temperature under dark conditions), changes in seed proteins, in particular, rapid changes in tunicamycin and phytochrome were observed.

In this study, we could not elucidate the correlation between the physiological changes in the seed and the mechanism of germination. Further research on seed dormancy and germination should be conducted to identify physiological mechanisms, thereby enabling us to clarify the germination conditions of T. uchiyamae seeds.

Acknowledgements. This work was supported by the National Research Foundation of Korea Grant funded by the Korean Government (NRF-2019R1I1A2A01062559) and the project "Ex-situ Conservation of Forest Plant Seeds in Korea" (KNA1-2-29).

\section{REFERENCES}

[1] Anderson, J. D., Johansson, H. J., Graham, C. S., Vesterlund, M., Pham, M. T., Bramlett, C. S., Montgomery, N. E., Mellema, S. M., Bardini, L. R., Contreras, Z., Hoon, M., Bauer, G., Fink, D. K., Fury, B., Hendrix, J. K., Chedin, F., EL-Andaloussi, S., Hwang, B., Mulligan, S. M., Lehtio, J., Nolta, A. J. (2016): Comprehensive proteomic analysis of mesenchymal stem cell exosomes reveals modulaton of angiogenesis via nuclear factorkappaB signaling. - Stem cells 34: 601-613.

[2] Badowiec, A., Weidner, S. (2014): Proteomic changes in the roots of germinating Phaseolus vulgaris seeds in response to chilling stress and post-stress recovery. - Journal of plant physiology 171: 389-398. 
[3] Bae, M. S., Cho, E. J., Choi, E.-Y., Park, O. K. (2003): Analysis of the Arabidopsis nuclear proteome and its response to cold stress. - Plant J 36: 652-663.

[4] Barba-Espín, G., Dedvisitsakul, P., Hägglund, P., Svensson, B., Finnie, C. (2014): Gibberellic acid-induced aleurone layers responding to heat shock or tunicamycin provide insight into the $\mathrm{N}$-glycoproteome, protein secretion, and endoplasmic reticulum stress. Plant physiology 164: 951-965.

[5] Baskin, J. M., Baskin, C. C. (1987): Temperature requirements for after-ripening in buried seeds of four summer annual weeds. - Weed Research 27: 385-389.

[6] Baskin, C. C., Baskin, J. M. (1998): Seeds: ecology, biogeography, and, evolution of dormancy and germination. - Elsevier, Academic Press.

[7] Baskin, J. M., Baskin, C. C. (2004): A classification system for seed dormancy. - Seed Science Research 14: 1-16.

[8] Bewley, J. D., Black, M. (1994): Seeds: Physiology of Development and Germination Plenum. - Press New York Google Scholar.

[9] Bewley, J. D., Black, M., Halmer, P. (eds.) (2006): The encyclopedia of seeds: science, technology and uses. - Wallingford, UK, CABI.

[10] Blackstock, W. P., Weir, M. P. (1999): Proteomics: quantitative and physical mapping of cellular proteins. - Trends in biotechnology 17: 121-127.

[11] Chen, G., Ramachandran, C., Krishan, A. (1993): Thaliblastine, a plant alkaloid, circumvents multidrug resistance by direct binding to P-glycoprotein. - Cancer Research 53: 2544-2547.

[12] Christenhusz, M. J. M., Byng, J. W. (2016): The number of known plants species in the world and its annual increase. - Phytotaxa 261: 201-217. doi:10.11646/phytotaxa.261.3.1.

[13] Chung, G. Y., Chang, K. S., Chung, J. M., Choi, H. J., Paik, W. K., Hyun, J. O. (2017): A checklist of endemic plants on the Korean Peninsula. - Korean Journal of Plant Taxonomy 47: 264-288.

[14] De La Fuente, M., Borrajo, A., Bermúdez, J., Lores, M., Alonso, J., López, M., Santalla, M., De Ron, A., Zapata, C., Alvarez, G. (2011): 2-DE-based proteomic analysis of common bean (Phaseolus vulgaris L.) seeds. - Journal of Proteomics 74: 262-267.

[15] Dogra, V., Ahuja, P. S., Sreenivasulu, Y. (2013): Change in protein content during seed germination of a high altitude plant Podophyllum hexandrum Royle. - Journal of proteomics 78: 26-38.

[16] Earle, T. T. (1938): Embryology of certain Ranales. - Botanical Gazette 100: 257-275.

[17] Engell, K. (1995): Embryo morphology of the Ranunculaceae. - In: Systematics and Evolution of the Ranunculiflorae, Springer Vienna.

[18] Eun-mi Bang. (1982): Study ( I ) on compound from the roots of Thalictrumm uchiyamai nakai. (in Korean).

[19] Fenner, M. K., Fenner, M., Thompson, K. (2005): The ecology of seeds. - Cambridge University Press.

[20] Ghimire, B., Lee, H., Choi, G., Jeong, M., Suh, U. G., Lee, H. C., Heo, K., Son, W. S. (2016): Seed morphology of 12 taxa of the genus Thalictrum L. (Thalictroideae, Ranunculaceae) and its systematic implication. - Phytotaxa 283: 271-285.

[21] He, D., Yang, P. (2013): Proteomics of rice seed germination. - Frontiers in plant science 4: 246.

[22] Hepher, A., Roberts, J. A. (1985): The control of seed germination in Trollius ledebouri: The breaking of dormancy. - Planta 166: 314-320.

[23] Hong, S. Y., Yoo, D. L., Kim, S. J., Nam, C. W., Ryu, S. Y., Suh, J. T. (2006): Effect of Low Temperature for the Breaking Dormancy of Primula sieboldii, P. modesta var. fauriae and Disporum smilacinum. - Korean Journal of Plant Resources 19: 45-49.

[24] Iwatsuki, K., Boufford, D. E., Ohba, H. (2006): Flora of Japan Vol. IIa. Angiospermae Dicotyledoneae Archlamydeae (a). - Kodansha, Tokyo. 
[25] Kim, K. M. (1993): Flavonoids from the aerial part of Thalictrum uchiyamai. - Ewha Womans University Graduate School. (in Korean).

[26] Kim, S. T., Kang, S. Y., Wang, Y., Kim, S. G., Hwang, D. H., Kang, K. Y. (2008): Analysis of embryonic proteome modulation by $\mathrm{GA}$ and $\mathrm{ABA}$ from germinating rice seeds. Proteomics 8: 3577-3587.

[27] Lee, I. R. (1984): Isolation and identification of phenolic tertiary and quaternary alkaloids from Thalictrum uchiyamai. - Yakhak Hoeji 28: 185-190.

[28] Lee, I. R., Lee, M. M. (1982): Studies of Chemical Constituents of the Genus Thalictrum in Korea (I)-Alkaloids from the Root of Thalictrum uchiyamai Nakai. - Korean Journal of Pharmacognosy 13: 132-135.

[29] Lee, S. Y., Rhie, Y. H., Kim, K. S. (2018): Dormancy breaking and germination requirements of seeds of Thalictrum uchiyamai (Ranunculaceae) with underdeveloped embryos. - Scientia Horticulturae 231: 82-88.

[30] Martin, A. C. (1946): The comparative internal morphology of seeds. - The American Midland Naturalist 36: 513-660.

[31] Matsuo, K., Kubota, T. (1988): Effect of temperature and light conditions on the breaking of seed dormancy and the germination of Chenopodium album L. - Weed Research (Japan) 33: 293-300.

[32] Nikolaeva, M. G. (1969): Physiology of deep dormancy in seeds. - Isreal Program for Scientific Translations, Jerusalem.

[33] Oh, B. U., Jo, D. G., Kim, K. S., Jang, C. G. (2005): Endemic Vascular Plants in Korean Peninsula ( $1^{\text {st }}$ step result). - Korea National Arboretum, Pocheon. (in Korean).

[34] Paik, W. K. (1999): The status of endemic plants in Korea and our tasks in the $21^{\text {st }}$ century. - Korean Journal of Plant Taxonomy 29: 263-274. (in Korean).

[35] Pajeva, I., Todorov, K. D., Seydel, J. (2004): Membrane effects of the antitumor drugs doxorubicin and thaliblastine: comparison to multidrug resistance modulators verapanil and trans-flupentixol. - European Journal of Pharmaceutical Science 21(2-3): 243-250. http://dx.doi.org/10.1016/j.ejps.2003.10.013.

[36] Park, O. K. (2004): Proteomic studies in plants. - Journal of biochemistry and molecular biology 37: 133-138.

[37] Park, S. J., Park, S. J. (2008): The morphology of Thalictrum L. in Korea. - Korean Journal of Plant Taxonomy 38: 433-458.

[38] Rana, B., Sreenivasulu, Y. (2013): Protein changes during ethanol induced seed germination in Aconitum heterophyllum. - Plant science 198: 27-38.

[39] Razem, F. A., Baron, K., Hill, R. D. (2006): Turning on gibberellin and abscisic acid signaling. - Curr. Opin. Plant Biol 9: 454-459.

[40] Reis, P. A., Rosado, G. L., Silva, L. A., Oliveira, L. C., Oliveira, L. B., Costa, M. D., Alvim, F. C., Fontes, E. P. (2011): The binding protein BiP attenuates stress-induced cell death in soybean via modulation of the N-rich proteinmediated signaling pathway. - Plant Physiol 157: 1853-1865.

[41] Rouquie, D., Peltier, J. B., MarquisMansion, M., Tournaire, C., Doumas, P., Rossignol, M. (1997): Construction of a directory of tobacco plasma membrane proteins by combined two-dimensional gel electrophoresis and protein sequencing. - Electrophoresis 18: 654660.

[42] Salisbury, F. B., Ross, C. W. (1985): Plant Physiology (3 ${ }^{\text {rd }}$ ed.) Wadsworth. - Belmont, California.

[43] Satoh, S., Esashi, Y. (1979): Protein Synthesis in Dormant and Non-Dormant Cocklebur Seed Segments. - Physiologia Plantarum 47: 229-234.

[44] Scott, S. J., Jones, R. A., Williams, W. (1984): Review of data analysis methods for seed germination. - Crop science 24: 1192-1199.

[45] Shin, A. Y., Han, Y. J., Baek, A., Ahn, T., Kim, S. Y., Nguyen, T. S., Son, M., Lee, W. K., Song, S. P., Kim, J. I. (2016): Evidence that phytochrome functions as a protein kinase in plant light signalling. - Nature communications 7: 1-13. 
[46] Song, K. S., Jeon, K. S., Choi, K. S., Kim, C. H., Park, Y. B., Kim, J. J. (2015): Effects of Storage Duration with Low Temperature and Wet Condition, Germination Temperature and Shading Rate on Germination of Aruncus dioicus var. kamtschaticus Seeds. - Korean Journal of Medicinal Crop Science 23: 370-378.

[47] Tamura, M., Mizumoto, Y. (1972): Stages of embryo development in ripe seeds or achenes of the Ranunculaceae. - J. Jnp. Bot 47: 225-237.

[48] Vandelook, F., Bolle, N., Van Assche, J. A. (2007): Seed dormancy and germination of the European Chaerophyllum temulum (Apiaceae), a member of a trans-Atlantic genus. Annals of Botany 100: 233-239.

[49] Walck, J. L., Baskin, C. C., Baskin, J. M. (2000): Seeds of Thalictrum mirabile (Ranunculaceae) require cold stratification for loss of nondeep simple morphophysiological dormancy. - Canadian Journal of Botany 77: 1769-1776.

[50] Wang, L., Ma, H., Song, L., Shu, Y., Gu, W. (2012): Comparative proteomics analysis reveals the mechanism of pre-harvest seed deterioration of soybean under high temperature and humidity stress. - Journal of Proteomics 75: 2109-2127.

[51] Wang, W. Q., Liu, S. J., Song, S. Q., Møller, I. M. (2015): Proteomics of seed development, desiccation tolerance, germination and vigor. - Plant Physiology and Biochemistry 86: 115 .

[52] Weiss, D., Ori, N. (2007): Mechanisms of cross talk between gibberellin and other hormones. - Plant Physiol. 144: 1240-1246.

[53] Yang, P., Li, X., Wang, X., Chen, H., Chen, F., Shen, S. (2007): Proteomic analysis of rice (Oryza sativa) seeds during germination. - Proteomics 7: 3358-3368. 


\section{APPENDIX}

Supplementary Table 1. Change in protein spots between cold-treated and non-treated seeds

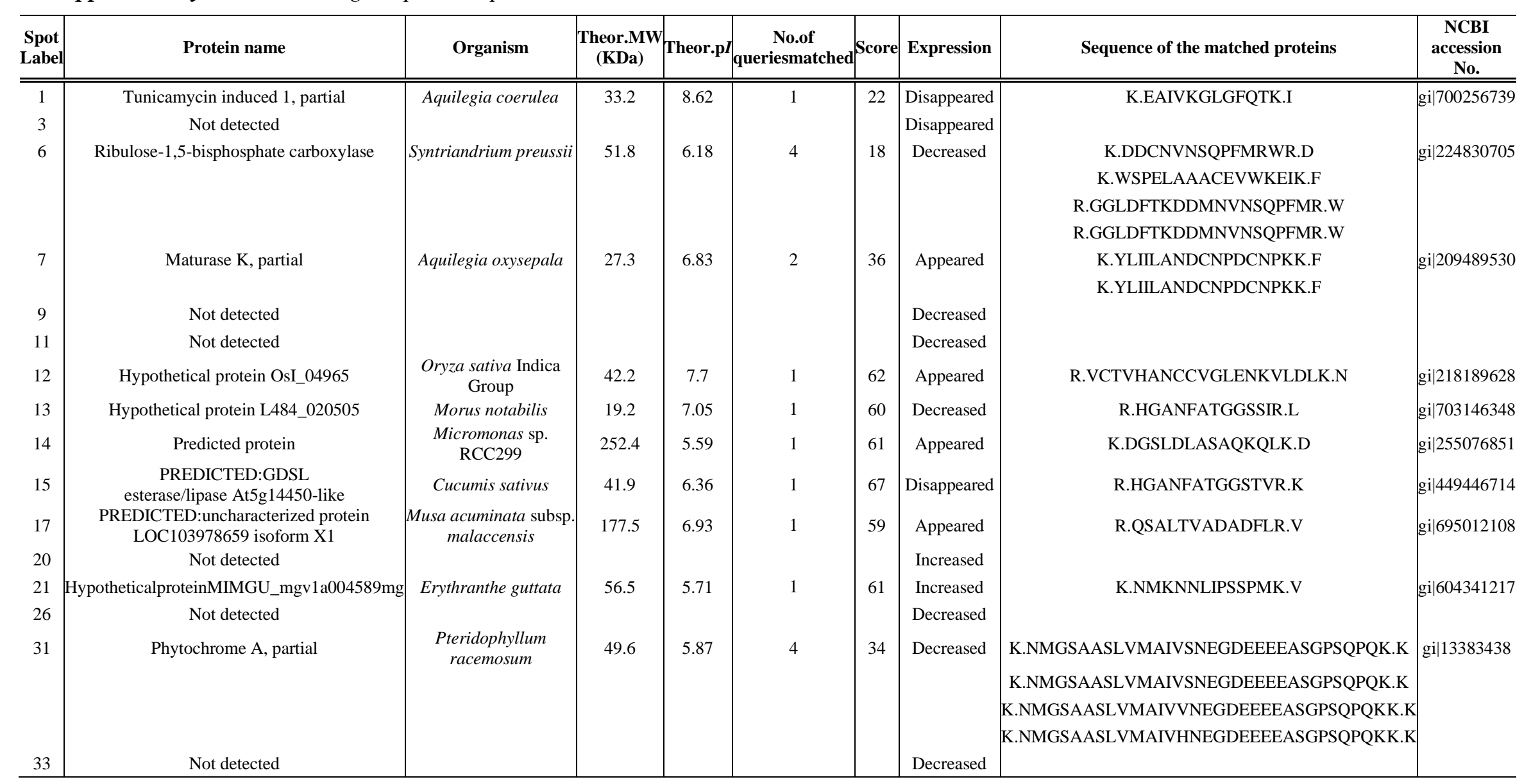

APPLIED ECOLOGY AND ENVIRONMENTAL RESEARCH 19(5):3643-3654.

http://www.aloki.hu • ISSN 15891623 (Print) • ISSN 17850037 (Online)

DOI: http://dx.doi.org/10.15666/aeer/1905_36433654

(c) 2021, ALÖKI Kft., Budapest, Hungary 